\title{
Seçilmiş OECD Ülkelerinde Yenilenebilir Enerji Tüketiminin Makro Ekonomik Belirleyicileri ${ }^{1}$
}

\author{
Ŭ̆ur YILDIRIM \\ Sorumlu Yazar, Kırlkkale Üniversitesi, İ̈BF, İktisat Bölümü \\ u.yildirim@kku.edu.tr, ORCID: 0000-0002-3542-7835 \\ M. Veysel KAYA \\ Kirıkkale Üniversitesi, IIIBF, İktisat Bölümü \\ mveyselkaya@yahoo.com,ORCID: 0000-0001-9322-1694
}

\begin{abstract}
$\ddot{\mathbf{O} z}$
Teknolojik gelişmeler ve yakın dönemde yaşanan çevresel bozulma Dünya’yı yeni bir dönüşümün eşiğine getirmiştir. Bu dönüşüm yeni üretim biçimlerinin ve ekonomik yapıların ortaya çıkacağının sinyallerini vermektedir. Bu bağlamda çevre ile uyumlu yeni ekonomik sistem, doğal olarak yenilenebilir enerji kaynaklarının öneminin artmasına tanıklık edecektir. Bu çalışma, seçilmiş OECD ülkelerinde yenilenebilir enerji kullanımını belirleyen faktörleri incelemektedir. Ayrıca yenilenebilir enerji kullanımının bu değişkenler üzerindeki etkileri de araştırılmıştır. Çalışmada, 1996 ile 2017 yılları arası dönem panel ARDL yöntemi ile altı farklı model kullanılarak incelenmiştir. Çalıșmanın temel amacı yenilenebilir enerji teknolojisi bakımından gelişmiș olan OECD ülkelerinin makro ekonomik yapılarını analiz etmektir. Elde edilen bulgular, karbondioksit (CO2) salınımının yenilenebilir enerji kullanımının en güçlü belirleyicisi olduğunu göstermiştir. Aynı zamanda cari işlemler dengesi, ekonomik büyüme, enflasyon ve petrol fiyatları da yenilenebilir enerji kullanımını etkilemektedir. Elde edilen bir başka sonuç ise yenilenebilir enerji kullanımının diğer değişkenleri güçlü biçimde etkileyecek düzeyde olmadığıdır.
\end{abstract}

Anahtar Kelimeler: Yenilenebilir Enerji, OECD Ülkeleri, Panel ARDL

Jel Sinıflandırma Kodları: K32, E21

Macroeconomic Determinants of Renewable Energy Consumption in Selected OECD Countries ${ }^{2}$

\begin{abstract}
Technological developments and recent environmental degradation have brought the world to the brink of a new transformation. This transformation indicates the emergence of new forms of production and new economic structures. In this context, the new economic system compatible with the environment will naturally witness the increase in the importance of renewable energy resources. This study examines the factors that determine the use of renewable energy in selected OECD countries. Furthermore, the impact of renewable energy consumption on these variables were also examined. In the study, the period between 1996 and 2017 was examined by using six different models with the panel ARDL method. The purpose of this paper is to analyze the macroeconomic structures of OECD countries, which are developed in terms of renewable energy technology. The results of these analyses illustrate that carbon dioxide (CO2) emission is the strongest determinant of renewable energy usage. Besides, current account balance, economic growth, inflation and oil prices also affect the consumption of renewable energy. Another result of this paper is the consumption of renewable energy does not strongly affect other variables.
\end{abstract}

Keywords: Renewable Energy, OECD Countries, Panel ARDL

Jel Classification Codes: K32, E21

\footnotetext{
${ }^{1}$ Bu çalışma yazarlardan Uğur Yıldırım’ın Kırıkkale Üniversitesi Sosyal Bilimler Enstitüsü İktisat Anabilim Dalı'nda hazırlamış olduğu aynı isimli doktora tezinden türetilmiştir

${ }^{2}$ Extended abstract is presented at the end of the article.
}

Geliş Tarihi (Received): 23.12.2020 - Kabul Edilme Tarihi (Accepted): 06.05.2021

Atıfta bulunmak için / Cite this paper:

Yıldırım, U. ve Kaya, M. V. (2021). Seçilmiş OECD ülkelerinde yenilenebilir enerji tüketiminin makro ekonomik belirleyicileri. Çankırı Karatekin Üniversitesi İ̈BF Dergisi, 11 (1), 267-289. Doi: 10.18074/ckuiibfd.845859. 


\section{Giriş}

Üretim teknolojileri, ekonomik yapı üzerinde tarih boyunca önemli rol oynamıştır. Enerji ise üretimin en temel girdilerinden biridir ve hangi enerji kaynağının kullanılacağı büyük ölçüde teknoloji tarafindan belirlenir. Kullanılan enerji kaynaklarının değişimi başka bir anlatımla yeni enerji kaynaklarının bulunması buharlı kazanların ortaya çıkışı gibi gelişmeler, önemli ekonomik sıçramalara yol açmıştır. Teknolojik sıçramalar ve yeni enerji kaynaklarının kullanımının etkileri ötesinde enerji çok kritik bir üretim girdisidir. Enerji sektöründe görülen petrol krizi gibi dar boğazlar ve maliyet artışları, Keynesyen akımın sona ermesi gibi önemli paradigma kaymalarına yol açmıştır. Günümüzde var olan ekonomik yapı, geleneksel enerji kaynaklarının tükenmesi ve daha önemlisi çevreye verdikleri zarar nedeni ile sürdürülemez bir boyuta ulaşmıştır. Son teknolojik gelişmeler çerçevesinde Dünya ekonomisi ve yaşam biçiminin önemli bir dönüşümün eşiğinde olduğu söylenebilir. Bu değişimin önemli dayanak noktalarından birinin sürdürülebilir enerji kaynaklarının etkin ve geniş bir alanda kullanılması olacağı beklenmektedir.

$\mathrm{Bu}$ çalışma yenilenebilir enerji tüketiminin belirleyicilerini ele almaktadır. $\mathrm{Bu}$ kapsamda söz konusu süreci tetikleyen unsurların neler olduğu makro ekonomik perspektiften araştırılmıştır. Araştırma yapılırken küresel ekonominin gelişmiş ve teknolojik yeniliklere öncülük eden seçilmiş Ekonomik Kalkınma ve İşbirliği Örgütü (OECD) ülkeleri incelenmiştir. $\mathrm{Bu}$ ülkelerde yenilenebilir enerji kullanımının temel makro ekonomik belirleyicileri araştırılmıştır. Ayrıca yenilenebilir enerji kullanımı ile petrol fiyatları, $\mathrm{CO} 2$ emisyonu arasındaki ilişki de incelenmiştir. Özetle bu çalışma makro ekonomik değişkenler ile bunun yanında $\mathrm{CO} 2$ emisyonu ve petrol fiyatlarının yenilenebilir enerji kullanımı üzerindeki etkilerini makro ekonomik perspektiften analiz etmektedir. Bu amaçla, araştırma için yenilenebilir enerji kullanımın yaygınlaştığı bir dönem aralığı olan 2000 yılı sonrası süreç seçilmiştir. Böylece enerji alanındaki yeni yönelimler ile bu yeniliklerin seçilen değişkenler ile olan ilişkilerine ve gelecekte ortaya çıkacak muhtemel gelişmelere 1 şı tutulmaya çalışılmıştır. Ayrıca politika yapıcılar için öneriler sunulması amaçlanmıştır.

Analizde, panel ARDL yöntemi ile yenilenebilir enerji kullanımı üzerine etkisi olan değişkenlerin belirlenmesi hedeflenmiştir. Çalışmada sırası ile literatür hakkında bilgi verilmiş ve kullanılan ekonometrik model ve veri seti açıklanmıştır. Daha sonra analiz sonucunda elde edilen bulgular raporlanmıştır. Sonuç bölümünde ise elde edilen bulgular iktisadi açıdan değerlendirilmiştir.

\section{Literatür}

Yenilenebilir enerji konusunda literatürde niceliksel bir artış söz konusudur. Büyüme, çevre, işsizlik ve petrol fiyatları gibi farklı değişkenler ile enerji ilişkisini ele alan çalışmalar bulunmaktadır. Bu çalışmaların öne çıkanları kısaca 
özetlenmiştir. Sadorsky (2009), kişi başına reel gelirdeki artışın, kişi başına yenilenebilir enerji tüketimini pozitif etkilediğini hesaplamıştır. Ayrıca Menyah ve Wolde-Rufael tarafından (2010) yapılan bir başka çalışmada yenilenebilir enerji kullanımı ile reel gayri safi yurtiçi hasıla (GSYIH) arasında pozitif bir ilişki görülmüştür. Apergis ve diğerleri (2010) yenilenebilir enerji kullanımı ile ekonomik büyüme arasında çift yönlü bir nedensellik olduğu sonucuna ulaşmıştır. Al-Mulali ve diğerlerinin (2015) yaptıkları çalışmaya göre, GSYİH'da görülen artışlar, yenilenebilir enerji kullanımını belirgin biçimde pozitif yönde etkilemektedir. Bloch ve diğerlerinin (2015) yaptıkları çalışmada, yenilenebilir enerji tüketimi ile ekonomik büyüme arasında çift yönlü uzun dönemli bir ilişki olduğunu rapor edilmiştir. Aynı yıl Ibrahiem (2015) tarafından yapılan araştırmanın bulguları da benzerdir. Lotz (2016), 34 OECD ülkesini araştırmıştır ve bulgular yenilenebilir enerji tüketiminin ekonomik büyüme üzerinde pozitif etkisinin olduğu yönündedir. Bölük ve Mert'in (2014) 16 Avrupa Birliği ülkesini kapsayan çalışmasında benzer bulgu raporlanmıştır. Aynı sonuca, Bhattacharya ve diğerleri (2017) yılında gerçekleştirdikleri çalışmada ulaşmıştır. Ek olarak Ito'nun (2017) çalışması da benzer sonuçları ortaya koymuştur. Bu çalışmalar yenilenebilir enerji kullanımı ile ekonomik büyüme arasında önemli ilişkilerin varlığını işaret etmektedir. Yenilenebilir enerji kullanımı üzerinde çevre faktörünün çok önemli olduğunu rapor eden araştırmalar vardır. Khattak ve diğerlerinin (2020) yaptıkları çalışmanın bulguları, yenilenebilir enerji tüketiminin, CO2 emisyonlarını negatif yönde etkilediğini göstermiştir. Jebli ve diğerlerinin (2020) yaptıkları çalışma, orta ve düşük gelirli ülkeler dışında yenilenebilir enerji tüketiminin tüm ülkelerde $\mathrm{CO} 2$ emisyonlarını azalttığını göstermiş̧tir. Ayrıca yenilenebilir enerji kullanımının işgücü piyasasını etkilediğini gösteren çalışmalar vardır. Hillebrand ve diğerlerinin (2006) yaptığı araştırma, yenilenebilir enerji kullanımının işsizliği azaltabilecek potansiyeli olduğunu göstermiştir. Wei ve diğerleri (2010) konuya ilişkin literatürde yer alan 15 farklı çalışmayı incelemişlerdir. Yenilenebilir enerji endüstrisinin istihdam sağlama potansiyelini analiz eden ve hepsi istihdam üzerinde belirgin bir şekilde pozitif etki rapor eden 13 çalışma olduğu görülmüştür. Ayrıca Iglinski ve diğerleri (2016) yayınladıkları çalışmalarında, yüksek işsizlik oranlarının, yenilenebilir enerji kaynaklarının gelişimini desteklediğini vurgulamışlardır. Dvorak ve diğerlerinin (2017) yaptığ 1 araştırmada ise yenilenebilir enerji sektörünün gelişiminin, işsizlik oranlarını azaltma üzerinde olumlu bir etkisi olduğunu göstermiştir. Literatürdeki bazı araştırmalar, yenilenebilir enerji ile ikamesi olan yenilenemeyen enerji arasındaki maliyet farklarının etkilerini araştırmıştır. Bird ve diğerlerinin (2005) yaptıkları çalışma, yüksek toptan elektrik fiyatlarının rüzgar enerjisi üretiminin rekabet gücünü artırdığını göstermiştir. Shah ve diğerlerinin (2018) gerçekleştirdikleri çalışmaya göre, petrol fiyatlarındaki artışlar, yenilenebilir enerji yatırımlarını açıklamada önemli etkiye sahiptir. Diğer yandan enerji önemli bir diş ticaret kalemidir. Literatürde bu konuda yapılmış araştırmalar da mevcuttur. Chang ve diğerlerinin (2009) gerçekleştirdiği çalışmaya göre, cari açığın, yenilenebilir enerji üretimini olumlu yönde etkileyebileceğini göstermiştir. 
Ayrıca Vaona (2016) tarihli çalışmasında, yenilenebilir enerji üretiminin artırılması ve ithalattaki büyümenin azaltılmasıyla, bir ülkenin dış ticaret açılarının önemli ölçüde düzeltilebileceğini rapor etmiştir.

\section{Uygulama}

\subsection{Veriler ve Kukla Değişken}

Çalışmada 26 OECD ülkesine ${ }^{3}$ ait ve 1996 ile 2017 yıllarını arası dönemi kapsayan yıllık veriler kullanılmıştır. Yapılan analiz, verilerin elde edilebildiği en geniş zaman dönemini kapsamaktadır. Söz konusu veriler; cari denge, bütçe dengesi, ekonomik büyüme, enflasyon, yenilenebilir enerji tüketimi, işsizlik oranı, karbondioksit salınımı ve ham petrol fiyatlarıdır. Bu değişkenlere ilişkin toplam gözlem sayısı 572'dir. Ekonomik büyüme ve yenilenebilir enerji tüketimi verileri $\frac{X_{t}-X_{t-1}}{X_{t}} \times 100$ formülü yardımı ile büyüme oranına çevrilmiştir. Diğer değişkenlerden enflasyon, cari denge, bütçe dengesi, işsizlik verileri, elde edildiği veri tabanından alınıp, tanımladığı biçimde kullanılmıştır. Cari denge verisinin pozitif değerler alması ülkelerin cari fazla vermesi olarak tanımlanmaktadır. Bütçe dengesi değişkeni de negatif değerlerler aldığında kamu bütçesinde ortaya çıkan açığı ifade etmektedir. Söz konusu değerlerin GSYİH'ya oranları veri tabanında yer almaktadır ve çalışmada veri tabanında tanımlandığı biçimi ile kullanılmıştır. İşsizlik verileri ise toplam işsizlik oranlarını yansıtmaktadır. $\mathrm{CO} 2$ salınımı ve ham petrol fiyatlarına ait veriler $\mathrm{CO} 2$ salınım düzeylerini ve Brent Petrol'ün varil fiyatını ifade etmektedir. $\mathrm{Bu}$ veri seti diğerlerinden farklılık arz etmekte ve zaman içinde ortaya çıkan $\mathrm{CO} 2$ salınımı ile ham petrol fiyatlarını yansıtmaktadır. $\mathrm{Bu}$ nedenle söz konusu verilerin logaritması alınmış ve daha sonra analize dahil edilmiştir. Bu aşamada belirtilmesi gereken önemli nokta, benzer karaktere sahip bir veri setinin herhangi bir ekonometrik modelde bağımlı ya da bağımsız değişken olarak kullanılması halinde, doğrusal olmayan ilişkileri yakalamak açısından logaritmasının alınarak kullanılması en uygun yöntem olarak benimsenmiş olduğudur. $\mathrm{Bu}$ nedenle petrol fiyatları ve $\mathrm{CO} 2$ salınımı veri setlerinin logaritması alınarak çalışmada veri setine dahil edilmiştir. Dünya Bankası'nın veri tabanından elde edilen veriler; İșsizlik Oranları ${ }^{4}$, Ekonomik Büyüme $^{5}$ (GSYIH), Enflasyon ${ }^{6}$ ve Cari İşlemler Dengesi ${ }^{7}$ olmuştur. OECD’nin veri tabanından elde edilen veriler; Kamu Bütçe Dengesi ${ }^{8}$ ve Yenilenebilir Enerji

\footnotetext{
${ }^{3}$ Avustralya, Kanada, İsviçre, Çek Cumhuriyeti, Almanya, Danimarka, İspanya, Estonya, Finlandiya, Fransa, Birleşik Krallık, Yunanistan, Macaristan, İsrail, İtalya, Güney Kore, Litvanya, Letonya, Hollanda, Norveç, Polonya, Portekiz, Slovak Cumhuriyeti, Slovenya, İsveç, Amerika Birleşik Devletleri

${ }^{4}$ https://data.worldbank.org/indicator/SL.UEM.TOTL.ZS (Erişim tarihi:10.01.2020)

${ }^{5}$ https://data.worldbank.org/indicator/NY.GDP.MKTP.KD (Erişim tarihi:29.12.2019)

${ }^{6} \mathrm{https} / / /$ data.worldbank.org/indicator/FP.CPI.TOTL.ZG (Erişim tarihi:29.12.2019)

${ }^{7} \mathrm{https}: / /$ data.worldbank.org/indicator/BN.CAB.XOKA.CD (Erişim tarihi:25.12.2019)

${ }^{8}$ https://data.oecd.org/gga/general-government-deficit.htm (Erişim tarihi:25.12.2019)
} 
Tüketimi ${ }^{9}$ verileridir. CO2 salınımı ${ }^{10}$ ve Ham Petrol Fiyatlarına ${ }^{11}$ ilişkin veriler de BP'nin veri tabanından elde edilmiştir.
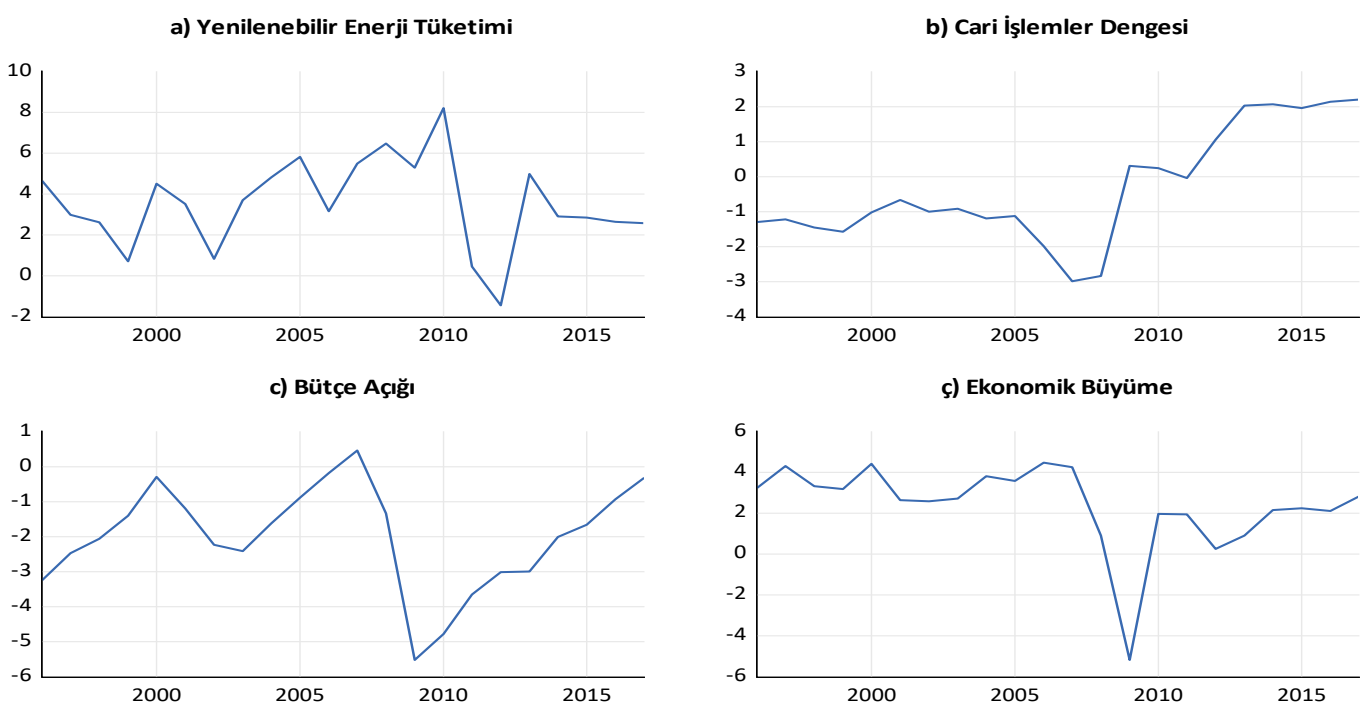

d) Enflasyon
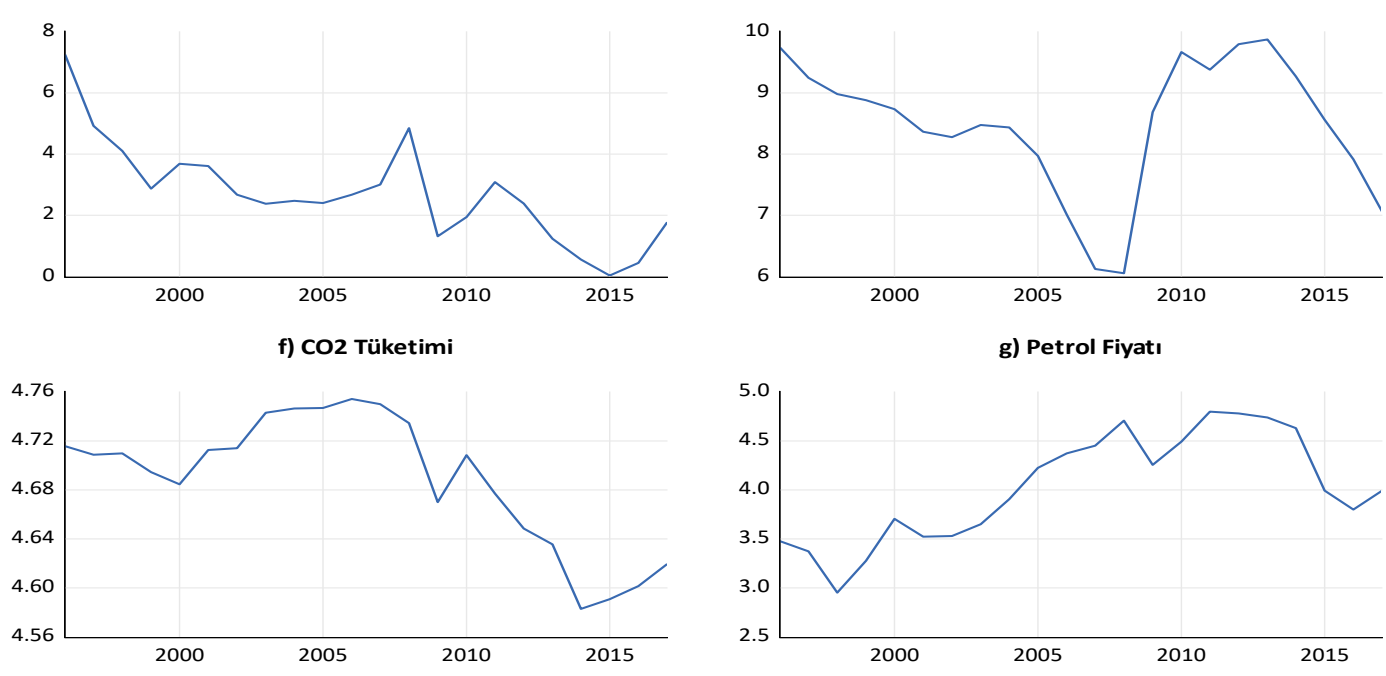

Şekil 1: Değişkenlere Ait Ülke Ortalaması Değerleri

Kaynak: Dünya Bankası (2019 ve 2020), OECD (2020) ve BP (2020) veri tabanlarından yararlanılarak düzenlenmiştir.

\footnotetext{
${ }^{9} \mathrm{https} / / /$ data.oecd.org/energy/renewable-energy.htm (Erişim tarihi:10.01.2020)

${ }^{10} \mathrm{https} / / / \mathrm{www} \cdot \mathrm{bp} . c 0 \mathrm{~m} / \mathrm{en} / \mathrm{global} / \mathrm{corporate} /$ energy-economics/statistical-review-of-worldenergy.html (Erişim tarihi:10.01.2020)

${ }^{11}$ https://www.bp.com/en/global/corporate/energy-economics/statistical-review-of-worldenergy.html (Erişim tarihi:10.01.2020)
} 
Şekil 1'de yer alan veri seti incelendiğinde ilk göze çarpan önemli nokta tüm değişkenler üzerinde 2007-2008 yıllarında yaşanan küresel ekonomik krizin etkilerinin gözlenmektedir. Bu durum, söz konusu yılların etkilerini ortaya koymak için çalışmada kukla değişken kullanmanın gerekliliğini ortaya koymaktadır. Bu sayede yapılan ekonometrik analiz, küresel krizin etkilerini de ortaya koymuştur. Literatür incelendiğinde de konuya ilişkin yapılan çalışmaların küresel krizin etkilerini analizlerine dahil etmiş olduğu da görülmektedir (Bknz Peters $^{12}$ vd., 2012).

\subsection{Testler}

Öncelikli olarak veri setinin özelliklerini belirlemek için araştırmalar yapılmıştır. Bu kapsamda değişkenlerin yatay kesit bağımlılıkları, birim kök analizleri ve eşbütünleşme analizleri gerçekleştirilmiştir. Verilerin yatay kesit bağımlılığ 1 gösterdiği anlaşılmıştır. Değişkenler, uygulanan çeşitli panel birim kök test analizlerine tabi tutulmuştur ve bazı değişkenlerin birim kök içermekte oldukları görülmüştür. Değişkenlerin bir kısmının da birim kök içermediği tespit edilmiştir. $\mathrm{Bu}$ nedenle değiş̧kenler arasında eş-bütünleşme olup olmadığı test edilmiş ve yapılan testler sonucu değişkenler arasında eş-bütünleşme olduğu da tespit edilmiştir. Veri setinin arz ettiği özellikler gözetilerek uygun yöntem seçilmiş ve çalışma gerçekleştirilmiştir. Aşağıda adı geçen testler ve sonuçları sıralanmıştır.

\subsubsection{Yatay Kesit Bağımlılık Testleri}

Panel veri modellerinde bu çalışmada olduğu gibi yatay kesit boyutu büyük ise genellikle panel veri modelleri, enine-kesit olarak bağımsız kabul edilmektedir. Ancak enine kesit gözlem sayısının 10'dan büyük olması durumunda hata terimlerinin çapraz korelasyonu durumu literatürde çeşitli yatay kesit bağımlılık testleri ile sınanmaktadırlar (Pesaran, 2004). Bu çalışmada kullanılan panel verilerin yatay kesit bağımlılığının test edilmesi ve daha sağlam sonuçlar edilebilmesi adına dört farklı test yöntemi kullanılmıştır. Bunlar; Breusch-Pagan LM, Pesaran Scaled LM, Pesaran CD ve Baltagi, Feng ve Kao Bias-Corrected Scaled LM testleridir. En çok bilinen panel veri yatay kesit testi Breusch-Pagan (1980) tarafından geliştirilmiştir. Fakat panel verinin yatay kesit uzunluğunun fazla olduğu durumlarda Breusch-Pagan LM testinin hatalı sonuçlar verebileceği için bu test yöntemine alternatif olarak Pesaran (2004) tarafindan Pesaran Scaled LM testi önerilmiştir. Ayrıca her iki yöntemde de kullanılan Lagrange Çarpanı (LM) test istatistiklerinin boyut çarpıklıklarını gidermek için yine Pesaran (2004) tarafından geliştirilen Pesaran CD test yöntemi kullanılan bir diğer test yöntemidir. Son olarak, Baltagi, Feng ve Kao (2012) tarafından ölçekli LM testi istatistiği için geliştirilen asimptotik sapma düzeltmesini göz önüne alan test istatistiği de çalışmada kullanılan tüm panel verilerin yatay kesit bağımlılıklarını

\footnotetext{
${ }^{12}$ Peters vd 2008-2009 Küresel Ekonomik Kriz sonrası CO2 emisyonunda yaşanan artışın nedenlerini kriz yılları için kukla değişken kullanarak benzer biçimde analiz etmişlerdir.
} 
ölçülmesinde kullanılan bir diğer başka test istatistiğidir. Bu dört farklı test de çalışmada kullanılarak verilerin yatay kesit bağımlılıkları detaylı biçimde araştırılmıştır. Aşağıdaki Tablo 1'de testlerin sonuçları sıralanmıştır. Tablodan görüldüğü üzere tüm değişkenler güçlü bir şekilde yatay kesit bağımlılık arz etmektedir.

Tablo 1: Yatay Kesit Bağımlıık Test Sonuçları

\begin{tabular}{lllll}
\hline Değişkenler & $\begin{array}{l}\text { Breusch-Pagan } \\
\text { LM }\end{array}$ & $\begin{array}{l}\text { Pesaran scaled } \\
\text { LM }\end{array}$ & $\begin{array}{l}\text { Bias-corrected } \\
\text { scaled LM }\end{array}$ & Pesaran CD \\
\hline Cari Denge & 1922,37 & 62,65 & 62,03 & 11,08 \\
& $(0,00)^{* * *}$ & $(0,00)^{* * *}$ & $(0,00)^{* * *}$ & $(0,00)^{* * *}$ \\
\hline Bütçe Dengesi & 1474,66 & 45,09 & 44,47 & 28,33 \\
& $(0,00)^{* * *}$ & $(0,00)^{* * *}$ & $(0,00)^{* * *}$ & $(0,00)^{* * *}$ \\
\hline Ekonomik & 2718,54 & 93,88 & 93,26 & 49,07 \\
Büyüme & $(0,00)^{* * *}$ & $(0,00)^{* * *}$ & $(0,00)^{* * *}$ & $(0,00)^{* * *}$ \\
\hline Enflasyon & 1863,65 & 60,35 & 59,73 & 36,50 \\
& $(0,00)^{* * *}$ & $(0,00)^{* * *}$ & $(0,00)^{* * *}$ & $(0,00)^{* * *}$ \\
\hline Yenilenebilir & 381,40 & 2,21 & 1,59 & 1,87 \\
Enerji Tüketimi & $(0,00)^{* * *}$ & $(0,00)^{* * *}$ & $(0,00)^{* * *}$ & $(0,00)^{* * *}$ \\
\hline İşsizlik & 1403,62 & 42,31 & 41,69 & 14,96 \\
& $(0,00)^{* * *}$ & $(0,00)^{* * *}$ & $(0,00)^{* * *}$ & $(0,00)^{* * *}$ \\
\hline CO2 Salınımı & 2608,91 & 89,58 & 88,96 & 26,61 \\
& $(0,00)^{* * *}$ & $(0,00)^{* * *}$ & $(0,00)^{* * *}$ & $(0,00)^{* * *}$ \\
\hline Petrol Fiyatı & 7150 & 267,70 & 267,08 & 84,56 \\
& $(0,00)^{* * *}$ & $(0,00)^{* * *}$ & $(0,00)^{* * *}$ & $(0,00)^{* * *}$ \\
\hline
\end{tabular}

Not: P değerleri parantez içinde gösterilmektedir. *, **, *** işaretleri sırasıyla $\% 10, \% 5$ ve $\% 1$ önem derecesini göstermektedir.

\subsubsection{Birim Kök Testleri ve Açıklamaları}

Yatay kesit bağımlılığına ilişkin yapılan test sonuçlarının yer aldığı Tablo 1'de görüldüğü üzere tüm değişkenler yatay kesit bağımlılığı arz etmektedir. $\mathrm{Bu}$ nedenle panel verilerin durağan olup olmadıkları Breitung ve Das (2005) tarafından geliştirilen birim kök testi ile analiz edilmiştir. Aşağıda yer alan Tablo 2'de çalışmada kullanılan değişkenlere ait panel birim kök test sonuçları yer almaktadır. Sabit terim içeren Breitlung birim kök testi sonuçlarına bakıldığında; cari denge, bütçe dengesi, ekonomik büyüme, yenilenebilir enerji tüketimi ve ham petrol fiyatı verilerinin $\% 1$ anlamlılı düzeyinde, enflasyon verisinin ise $\% 5$ anlamlılık düzeyinde birim kök içermediği yani durağan olduğu anlaşılmaktadır. Buna karşın işsizlik ve $\mathrm{CO} 2$ salınımı verilerinin birim kök içerdiği görülmektedir. Sabit terim ve trend bileşeni içeren Breitlung birim kök testi sonuçlarına bakıldığında ise; bütçe dengesi, ekonomik büyüme, enflasyon ve yenilenebilir enerji tüketimi verilerinin $\% 1$ anlamlılık düzeyinde durağan oldukları görülmüştür. Ancak cari açık, işsizlik, CO2 salınımı ve ham petrol fiyatı verilerinin durağan olmadıkları anlaşılmıştır. 
Tablo 2: Breitlung Birim Kök Testi Sonuçları

\begin{tabular}{lll}
\hline Değişkenler & Sabit Terim & Sabit Terim + Trend \\
\hline Cari Denge & $-2,43^{* * *}(0,0075)$ & $-0,59(0,2780)$ \\
\hline Bütçe Dengesi & $-5,12^{* * *}(0,0000)$ & $-3,30 * * *(0,0005)$ \\
\hline Ekonomik Büyüme & $-9,54 * * *(0,0000)$ & $-8,41^{* * *}(0,0000)$ \\
\hline Enflasyon & $-2,02^{* *}(0,0218)$ & $-2,90 * * *(0,0018)$ \\
\hline $\begin{array}{l}\text { Yenilenebilir Enerji } \\
\text { Tüketimi }\end{array}$ & $-8,95^{* * *}(0,0000)$ & $-8,82^{* * *}(0,0000)$ \\
\hline Isssizlik & $-1,25(0,1063)$ & $2,03(0,9786)$ \\
\hline CO2 Salınımı & $0,57(0,7167)$ & $-0,51(0,3060)$ \\
\hline Petrol Fiyatı & $-4,28^{* * *}(0,0000)$ & $2,06(0,9803)$ \\
\hline
\end{tabular}

Not: $\mathrm{P}$ değerleri parantez içinde gösterilmektedir. *, **, *** işaretleri sırasıyla $\% 10$, $\% 5$ ve $\% 1$ önem derecesini göstermektedir

Yapılan testler sonucunda çalışmada yer alan verilerin bir kısmının birim kök içerdiği buna karşın bir kısmının da birim kök içermediği anlaşılmıştır. Bu durum, yenilenebilir enerji tüketimi üzerinde etkisi olan makro ekonomik değişkenler ve çalışmada yer alan diğer değişkenler ile yenilenebilir enerji tüketimi arasındaki ilişkinin panel ARDL yöntemi ile incelenmesinin doğru tercih olduğunu ortaya koymaktadir.

\subsubsection{Eş-bütünleşme Testi}

Her ne kadar panel ARDL modelinin kullanılması için değişkenler arasında herhangi bir eş-bütünleşme olması gerekmese de değişkenler arasında eşbütünleşmenin varlığı panel ARDL modelinde yer alan uzun dönem ilişkiye sağlam bir kanıt olarak görülebilir. Bu nedenle, çalışmadaki uygulama bölümünün bu kısmında kullanılan veriler arasında eş-bütünleşme olup olmadığı Pedroni $(1999,2004)$ ve Westerlund (2005) eş-bütünleşme testleri yardımı ile test edilmiştir.

Aşağıda yer alan Tablo-3'te görülen eş-bütünleşme sonuçlarına göre bazı değişkenler arasında eş-bütünleşmenin olmadığına ilişkin boş hipotez her iki test türüne göre de güçlü bir şekilde reddedilmektedir. Başka bir anlatımla modelde kullanıla değişkenler arasında eş-bütünleşmenin olduğu görülmektedir. 
Tablo 3: Eş-bütünleşme Testi

\begin{tabular}{llll}
\hline Tür & $\begin{array}{l}\text { Westerlund } \\
\text { Eş-bütünleşme } \\
\text { Testi }\end{array}$ & Tür & $\begin{array}{l}\text { Pedroni } \\
\text { Eş-bütünleşme Testi }\end{array}$ \\
\hline VR & $-3,10(0,0010)$ & PP-M & $3,20(0,0007)$ \\
& & PP & $-28,77(0,0000)$ \\
& & ADF & $-23,02(0,0000)$ \\
\hline
\end{tabular}

Not: P değerleri parantez içinde gösterilmektedir.

Araştırmanın yöntemi açıklanmadan önce çalışmaya ilişkin diğer bilgilerin yer aldığı tablolara aşağıda yer verilmiştir. Tablo 4'te ülkelere ait panel verilerin tanımlayıcı istatistikleri ve Tablo 5'te ülkelere ait panel verilerin değişkenlerine ait korelasyon matrisi bulunmaktadır.

Tablo 4: Tanımlayıcı İstatistikler

\begin{tabular}{|c|c|c|c|c|c|c|}
\hline Değişken & $\begin{array}{c}\text { Gözlem } \\
\text { Sayıs1 }\end{array}$ & Ortalama & Medyan & Min & Maks & $\begin{array}{r}\text { Standart } \\
\text { Sapma } \\
\end{array}$ \\
\hline YET & 572 & 3,53 & 3,78 & 206,21 & 44,65 & 11,92 \\
\hline $\mathrm{CD}$ & 572 & $-0,33$ & $-2,30$ & $-21,07$ & 16,19 & 5,91 \\
\hline $\mathrm{BD}$ & 572 & $-1,99$ & $-0,69$ & $-15,14$ & 18,67 & 4,19 \\
\hline $\mathrm{EB}$ & 572 & 2,40 & 2,61 & $-17,39$ & 10,63 & 3,06 \\
\hline ENF & 572 & 2,71 & 2,11 & $-1,74$ & 24,63 & 3,08 \\
\hline İşsizlik & 572 & 8,48 & 7,58 & 2,05 & 27,47 & 4,40 \\
\hline $\mathrm{CO}_{2}$ & 572 & 4,69 & 4,22 & 1,94 & 8,68 & 1,49 \\
\hline Petrol Fiyat1 & 22 & 4,03 & 3,99 & 2,95 & 4,80 & 0,54 \\
\hline
\end{tabular}

Not: BA: Bütçe Dengesi; CD: Cari Denge; ENF: Enflasyon Oranı; EB: Ekonomik Büyüme; YET: Yenilenebilir Enerji Tüketimi; $\mathrm{CO}_{2}$ : Karbondioksit Salınımı

Tablo 5: Değişkenler Ait Korelasyon Matrisi

\begin{tabular}{ccccccccc}
\hline Değişkenler & YET & CD & BD & EB & ENF & İşsizlik & CO2 & $\begin{array}{l}\text { Petrol } \\
\text { Fiyat }\end{array}$ \\
\hline YET & 1.00 & & & & & & & \\
CD & -0.02 & 1.00 & & & & & & \\
BD & -0.03 & 0.49 & 1.00 & & & & & \\
EB & -0.05 & -0.21 & 0.25 & 1.00 & & & & \\
ENF & 0.04 & -0.38 & -0.13 & 0.16 & 1.00 & & & \\
İssizlik & 0.00 & -0.27 & -0.44 & -0.11 & 0.07 & 1.00 & & \\
CO2 & 0.08 & 0.04 & -0.14 & -0.09 & -0.16 & -0.15 & 1.00 & \\
Petrol & 0.03 & 0.07 & -0.06 & -0.24 & -0.19 & -0.02 & -0.01 & 1.00 \\
Fiyatı & & & & & & &
\end{tabular}

Not: BD: Bütçe Dengesi CD: Cari Denge; ENF: Enflasyon Oranı; EB: Ekonomik Büyüme; YET: Yenilenebilir Enerji Tüketimi, CO2: Karbondioksit Salınımı 


\subsection{Yöntem}

Veri setinin özellikleri incelendiğinde, değişkenler arasındaki ilişkinin Pesaran ve Smith (1999) ve Pesaran vd. (1995) tarafindan geliştirilen Panel ARDL yöntemi ile analiz edilmesinin en uygun olduğu görülmektedir. Çünkü Panel ARDL yöntemi sabit etkili, araçsal değişkenler ile GMM tahmin yöntemleri gibi Anderson ve Hsiao (1981,1982), Arellano (1989) ile Arellano ve Bover (1995) çalışmalarında da görüldüğü üzere, diğer dinamik panel veri regresyon yöntemlerine kıyasla daha üstün özelliklere sahiptir. Ülkeler arasında tahmin edilen katsayılar aynı olmadığı sürece, diğer yöntemlerin hatalı sonuçlar üretme olasılığ 1 vardır. Veri setinin benzer özellikler gösterdiği durumlarda Panel ARDL'nin en etkin yöntem olduğu D. Karadam (2015) tarafından yapılan ve yine bu tez çalışmasına benzer biçimde OECD ülkelerinin konu alan ve benzer bir veri setine sahip çalışmada da ortaya koyulmuştur. Literatürde yer alan çalışmalar ve uygulamaları 1şığında en uygun yöntemin Panel ARDL olacağı görülmüştür.

$\operatorname{ARDL}(\mathrm{p}, \mathrm{q}, \mathrm{q}, . . ., \mathrm{q})$ modeli aşağıdaki biçimde tanımlanabilir.

$Y_{i t}=\sum_{j=1}^{p} \alpha_{i j} Y_{i, t-j}+\sum_{j=1}^{q} \delta_{i j}^{\prime} X_{i, t-j}+\mu_{i}+\varepsilon_{i t}$

Yukarıda yer alan denklemde, $\mathrm{Y}$ bağımlı değişken iken $\mathrm{X}$ açıklayıcı değişkenlerdir. Model tekrar parametrize edildiğinde aşağıdaki yapıyı almaktadır.

$\Delta Y_{i t}=\emptyset_{i}\left(Y_{i, t-1}-\beta_{i}^{\prime} X_{i t}\right)+\sum_{j=1}^{p-1} \alpha_{i j}^{*} \Delta Y_{i, t-j}+\sum_{j=1}^{q-1} \delta_{i j}^{* \prime} X_{i, t-j}+\mu_{i}+\varepsilon_{i t}$

Yukarıda yer alan iki numaralı modelde $\beta_{i}$ elde edilmesi hedeflenen katsayılar olup modelde yer verilen açıklayıcı değişkenlerin yenilenebilir enerji tüketimi üzerindeki uzun dönem etkisini ortaya koymaktadır. Bunun yanında $\emptyset_{i}$ ise hata düzeltici mekanizma etkisi (Error Correction Mechanism Impact) olarak adlandırılan katsayıdır. Modelde yer alan diğer değişkenler ülkelere ait kısa dönem katsayıları göstermektedir. Zaman ve birimler arası bağımsız olan $\varepsilon_{i t}$ ise hata terimi olup ortalaması sifir ve varyansı sabittir. Modele daha yakından bakıldığında, değişkenlerin uzun dönem ve kısa dönemli etkilerinin ayrı ayrı inceleyebilme özelliği sunduğu görülmektedir. Bu durum, değişkenler arasındaki kısa ve uzun dönemli ilişkileri ayrı ayrı görebilmek açısından bir avantajıdır. Literatürde yer alan çalışmalar incelendiğinde Pesaran ve Smith (1999) ve Pesaran vd. (1995) Denklem (1)'de yer verilen modelin MG (Mean Group) yöntemi ile 
tutarlı bir şekilde tahmin edilebileceğini göstermişlerdir. Bu yöntemde, katsayılar her bir yatay kesit verisi için hesaplanmakta ve daha sonrasında ortalaması alınmaktadır. Ancak denklemde yer verilen uzun dönem katsayılar bu çalışmada olduğu gibi her bir ülke için homojenlik gösteriyorsa, Pesaran ve Smith (1999) ve Pesaran vd. (1995) çalışmalarında ifade edildiği gibi PMG (Pooled Mean Group) olarak isimlendirilen daha etkin bir yöntem önerilmektedir. PMG'ye göre, değişkenler arasındaki ilişki uzun dönemde aynı yapıya sahipken kısa dönem katsayılar ülkeden ülkeye değişiklik göstermektedir. Bu durum göz önüne alınarak, PMG yöntemi uygulanmış ve çalışmanın temel yöntemi olarak PMG yöntemi esas alınmıştır. Buna karşın $\mathrm{MG}$ yöntemi de uygulanarak bu yöntemin uygulaması sonucunda elde edilen bulgular da değerlendirilmiştir.

\subsubsection{PMG Model Sonuçları}

Aşağıda yer alan Tablo 6'da yenilenebilir enerji tüketimi ile bu değişkeni etkileyen diğer değişkenlerin analiz edildiği panel ARDL PMG sonuçlarına yer verilmektedir. Yapılan analizde 6 farklı model tahmini hem PMG hem de MG yöntemi ile tahmin edilmiştir. Her bir model için panel ARDL modelleri tahmin edildikten sonra bu modeller Hausman testine (Ayrıntılı bilgi için bknz. Baum, Schaffer ve Stillman, 2003) tabi tutulmuştur. Bununla birlikte tüm değişkenlere ait panel denklemler hem PMG hem de MG yöntemi ile tahmin edilmiş ve bu sonuçlar Hausman test ile karşılaştırılmıştır. Yapılan testlerde boş hipotez "PMG modeli tercih edilir. Her iki modelde tutarlı olmasına rağmen PMG MG'ye tercih edilir." olup tahmin edilen tüm modellerde boş hipotezin güçlü bir şekilde reddedilemediği görülmüştür. Tablo 6'de de görüleceği gibi yapılan Hausman testi sonucunda elde edilen p-değerleri söz konusu dört model için de 0,05 'ten büyük olması nedeni ile tüm denklemler için PMG modeli MG modeline tercih edilmiştir. Tablo 6'da yer verilen 6 farklı PMG modelinin her birinde değişkenler arasındaki ilişkilerin sınanması için 6 farklı bağımlı değişken kullanılmıştır. $\mathrm{Bu}$ sayede çalışmanın konusuna farklı açılardan yaklaşan altı farklı ekonometrik araştırma yapılmıştır. Çalışmada yer alan modeller ve modellerde kullanılan bağımlı ve bağımsız değişkenler sırasıyla aşağıda tanıtılmıştır.

Model 1: Bağımlı değişken yenilenebilir enerji tüketimi olup, sabit terim dahil olmak üzere diğer tüm değişkenler olan, cari işlemler dengesi, enflasyon oranı, ekonomik büyüme, bütçe dengesi, işsizlik ve petrol fiyatı verileri açıklayıcı değişken olarak modele dahil edilmiştir.

Model 2: Bağımlı değişken cari işlem dengesi değişkeni olup, sabit terimle birlikte yenilenebilir enerji tüketimi, enflasyon oran1, ekonomik büyüme, bütçe dengesi, işsizlik ve petrol fiyatı verileri açıklayıcı değişken olarak modele dahil edilmiştir.

Model 3: Bağımlı değişken bütçe dengesi değişkeni olup, sabit terimle birlikte yenilenebilir enerji tüketimi, enflasyon oran1, ekonomik büyüme, cari işlemler 
dengesi, işsizlik ve petrol fiyatı verileri açıklayıcı değişken olarak modele dahil edilmiştir.

Model 4: Bağımlı değişken ekonomik büyüme değişkeni olup, sabit terimle birlikte yenilenebilir enerji tüketimi, enflasyon oranı, bütçe dengesi, cari işlemler dengesi, işsizlik ve petrol fiyatı verileri açıklayıcı değişken olarak modele dahil edilmiştir.

Model 5: Bağımlı değişken enflasyon oranı değişkeni olup, sabit terimle birlikte yenilenebilir enerji tüketimi, bütçe dengesi, ekonomik büyüme, cari işlemler dengesi, işsizlik ve petrol fiyatı verileri açıklayıcı değişken olarak modele dahil edilmiştir.

Model 6: Bağımlı değişken işsizlik oranı değişkeni olup, sabit terimle birlikte yenilenebilir enerji tüketimi, enflasyon oran1, ekonomik büyüme, cari işlemler dengesi, bütçe dengesi ve petrol fiyatı verileri açıklayıcı değişken olarak modele dahil edilmiştir.

Aşağıda yer alan Tablo 6'da değişkenler arasındaki uzun ve kısa dönemli ilişkiler yer almaktadır. Tablo 6'da yer alan bilgiler çalışmaya konu olan ülkeler için elde edilen toplu sonuçlardır. Tablo 6'nın üst kısmı tüm ülkelerde aynı olduğu görülen uzun dönem ilişkiyi gösterirken, tablonun alt kısmı ise ülkeden ülkeye değişiklik gösteren kısa dönem ilişkilerin ortalamasını vermektedir. Tabloda yer verilen ve kalın harfler ile yazılan analiz sonuçları, istatistiksel olarak \%10 güven aralığında yer alan ve anlamlı olan bulguları göstermektedir. Bu kapsamda, tablonun en sol sütununda yer verilen bağımsız değişkenlerden katsayısı istatistiksel olarak anlamlı olanların her bir denklemdeki bağımlı değişken üzerinde (örneğin Denklem-1'de bağımlı değişken YET) etkili olduğu söylenebilir. Tüm modellerdeki hata terimi (Error correction-EC) katsayıları negatif olup istatiksel olarak anlamlı bulunmuştur. Ayrıca bu bulgular tahmin edilen tüm PMG modellerinin tutarlı 
Tablo 6: Panel ARDL Uzun Dönem PMG Tahminleri

\begin{tabular}{|c|c|c|c|c|c|c|c|}
\hline & & $\begin{array}{l}\text { Model (1) } \\
\text { YET }\end{array}$ & $\begin{array}{c}\text { Model } \\
\text { (2) } \\
\text { CD }\end{array}$ & $\begin{array}{c}\text { Model } \\
\text { (3) } \\
\text { BD }\end{array}$ & $\begin{array}{c}\text { Model } \\
(4) \\
\text { EB }\end{array}$ & $\begin{array}{c}\text { Model } \\
(5) \\
\text { ENF }\end{array}$ & $\begin{array}{c}\text { Model } \\
(6) \\
\text { İşsizlik }\end{array}$ \\
\hline \multirow{9}{*}{ 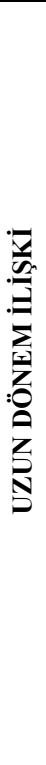 } & Yenilenebilir Enerji Tüketimi & Bağımlı D. & $\begin{array}{c}0.01 \\
(0.71)\end{array}$ & $\begin{array}{c}0.01 \\
(0.17)\end{array}$ & $\begin{array}{c}0.00 \\
(0.98)\end{array}$ & $\begin{array}{l}-\mathbf{0 . 0 3} \\
(\mathbf{0 . 0 0 )}\end{array}$ & $\begin{array}{l}-0.01 \\
(0.79)\end{array}$ \\
\hline & Cari Denge & $-0,21(0,00)$ & $\begin{array}{c}\text { Bağımlı } \\
\text { D. }\end{array}$ & $\begin{array}{c}0.29 \\
(0.00)\end{array}$ & $\begin{array}{c}0.04 \\
(0.02)\end{array}$ & $\begin{array}{c}-0.06 \\
(0.01)\end{array}$ & $\begin{array}{c}0.05 \\
(0.58)\end{array}$ \\
\hline & Bütçe Dengesi & $0,03(0,76)$ & $\begin{array}{c}1.40 \\
(0.00)\end{array}$ & $\begin{array}{l}\text { Bağımlı } \\
\text { D. }\end{array}$ & $\begin{array}{l}-0.03 \\
(0.29)\end{array}$ & $\begin{array}{c}-0.13 \\
(0.00)\end{array}$ & $\begin{array}{l}-1.09 \\
(0.00)\end{array}$ \\
\hline & Ekonomik Büyüme & $0,25(0,06)$ & $\begin{array}{l}-1.41 \\
(0.00)\end{array}$ & $\begin{array}{c}0.77 \\
(0.00)\end{array}$ & $\begin{array}{c}\text { Bağımlı } \\
\text { D. }\end{array}$ & $\begin{array}{c}0.32 \\
(0.00)\end{array}$ & $\begin{array}{l}-3.59 \\
(0.00)\end{array}$ \\
\hline & Enflasyon & $-0.33(0,01)$ & $\begin{array}{c}-0.56 \\
(0.00)\end{array}$ & $\begin{array}{c}-0.53 \\
(0.00)\end{array}$ & $\begin{array}{l}-0.03 \\
(0.47)\end{array}$ & $\begin{array}{l}\text { Bağımlı } \\
\text { D. }\end{array}$ & $\begin{array}{c}0.39 \\
(0.01)\end{array}$ \\
\hline & İşsizlik & $0.04(0.62)$ & $\begin{array}{c}0.75 \\
(0.00)\end{array}$ & $\begin{array}{c}-0.12 \\
(0.02)\end{array}$ & $\begin{array}{l}-0.04 \\
(0.16)\end{array}$ & $\begin{array}{l}-0.17 \\
(0.00)\end{array}$ & $\begin{array}{c}\text { Bağımlı } \\
\text { D. }\end{array}$ \\
\hline & CO2 Salınımı & $4.79(0,01)$ & - & - & - & - & - \\
\hline & Petrol Fiyatı & $0.80(0,03)$ & $\begin{array}{c}-3,10 \\
(0,00)\end{array}$ & $\begin{array}{c}0.27 \\
(0.26)\end{array}$ & $\begin{array}{c}-0.41 \\
(0.00)\end{array}$ & $\begin{array}{c}0.02 \\
(0.90)\end{array}$ & $\begin{array}{c}-1.30 \\
(0.01)\end{array}$ \\
\hline & Kukla Değişken & $0.26(0,61)$ & $\begin{array}{l}1.07 \\
(0.15)\end{array}$ & $\begin{array}{l}-0.66 \\
(0.03)\end{array}$ & $\begin{array}{c}-0.90 \\
(0.00)\end{array}$ & $\begin{array}{l}-0.09 \\
(0.57)\end{array}$ & $\begin{array}{l}-4.08 \\
(0.00)\end{array}$ \\
\hline \multirow{13}{*}{ 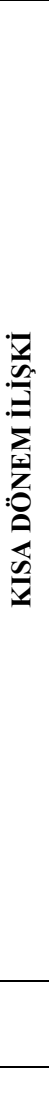 } & Hata terimi (EC) & $-1.16(0.00)$ & $\begin{array}{l}-0.16 \\
(0.00)\end{array}$ & $\begin{array}{c}-0.42 \\
(0.00)\end{array}$ & $\begin{array}{c}-0.98 \\
(0.00)\end{array}$ & $\begin{array}{l}-0.54 \\
(0.00)\end{array}$ & $\begin{array}{l}-0.11 \\
(0.00)\end{array}$ \\
\hline & Yenilenebilir Enerji Tüketimi & Bağımlı D. & $\begin{array}{c}0.00 \\
(0.63)\end{array}$ & $\begin{array}{c}0.01 \\
(0.35)\end{array}$ & $\begin{array}{c}0.00 \\
(0.71)\end{array}$ & $\begin{array}{c}0.02 \\
(0.01)\end{array}$ & $\begin{array}{c}0.01 \\
(0.02)\end{array}$ \\
\hline & Cari Denge & $0.74(0.03)$ & $\begin{array}{c}\text { Bağımlı } \\
\text { D. }\end{array}$ & $\begin{array}{l}-0.01 \\
(0.86)\end{array}$ & $\begin{array}{c}-0.29 \\
(0.00)\end{array}$ & $\begin{array}{c}0.10 \\
(0.00)\end{array}$ & $\begin{array}{c}0.07 \\
(0.04)\end{array}$ \\
\hline & Bütçe Dengesi & $0.69(0.15)$ & $\begin{array}{c}0.04 \\
(0.49)\end{array}$ & $\begin{array}{l}\text { Bağımlı } \\
\text { D. }\end{array}$ & $\begin{array}{c}0.28 \\
(0.00)\end{array}$ & $\begin{array}{c}0.04 \\
(0.39)\end{array}$ & $\begin{array}{c}0.03 \\
(0.42)\end{array}$ \\
\hline & Ekonomik Büyüme & $0.18(0.56)$ & $\begin{array}{l}-0.02 \\
(0.80)\end{array}$ & $\begin{array}{l}-0.10 \\
(0.07)\end{array}$ & $\begin{array}{l}\text { Bağımlı } \\
\text { D. }\end{array}$ & $\begin{array}{l}-\mathbf{- 0 . 0 9} \\
(0.00)\end{array}$ & $\begin{array}{c}0.13 \\
(0.00)\end{array}$ \\
\hline & Enflasyon & $0.22(0.62)$ & $\begin{array}{c}0.09 \\
(0.28)\end{array}$ & $\begin{array}{c}0.21 \\
(0.00)\end{array}$ & $\begin{array}{c}0.27 \\
(0.00)\end{array}$ & $\begin{array}{l}\text { Bağımlı } \\
\text { D. }\end{array}$ & $\begin{array}{l}-0.02 \\
(0.59)\end{array}$ \\
\hline & İş̧sizlik & $0.82(0.24)$ & $\begin{array}{c}0.46 \\
(0.00)\end{array}$ & $\begin{array}{l}-0.41 \\
(0.00)\end{array}$ & $\begin{array}{l}-0.85 \\
(0.00)\end{array}$ & $\begin{array}{c}0.09 \\
(0.29)\end{array}$ & $\begin{array}{l}\text { Bağımlı } \\
\text { D. }\end{array}$ \\
\hline & CO2 Salınımı & $\begin{array}{l}- \\
40.43(0.08)\end{array}$ & - & - & - & - & - \\
\hline & Petrol Fiyatı & $-0.23(0.85)$ & $\begin{array}{c}0.06 \\
(0.83)\end{array}$ & $\begin{array}{c}0.85 \\
(0.00)\end{array}$ & $\begin{array}{c}1.10 \\
(0.00)\end{array}$ & $\begin{array}{c}1.35 \\
(0.00)\end{array}$ & $\begin{array}{c}0.43 \\
(0.02)\end{array}$ \\
\hline & Kukla Değişken & $3.16(0.36)$ & $\begin{array}{l}-1.04 \\
(0.01)\end{array}$ & $\begin{array}{l}-0.62 \\
(0.07)\end{array}$ & $\begin{array}{l}-0.84 \\
(0.02)\end{array}$ & $\begin{array}{c}1.80 \\
(0.00)\end{array}$ & $\begin{array}{l}-0.04 \\
(0.89)\end{array}$ \\
\hline & Sabit Terim & $-25.72(0.0)$ & $\begin{array}{c}2.29 \\
(0.00)\end{array}$ & $\begin{array}{l}-1.05 \\
(0.00)\end{array}$ & $\begin{array}{l}4.56 \\
(0.00)\end{array}$ & $\begin{array}{c}1.25 \\
(0.00)\end{array}$ & $\begin{array}{c}2.19 \\
(0.00)\end{array}$ \\
\hline & Hausman Testi & $0,17(1,00)$ & $\begin{array}{c}2,84 \\
(0,90)\end{array}$ & $\begin{array}{c}1,05 \\
(0,99)\end{array}$ & $\begin{array}{c}2,48 \\
(0,93)\end{array}$ & $\begin{array}{c}1,34 \\
(0,99)\end{array}$ & $\begin{array}{c}1,67 \\
(0,98)\end{array}$ \\
\hline & Gözlem Sayısı & 572 & 572 & 572 & 572 & 572 & 572 \\
\hline
\end{tabular}




\subsection{Bulgular}

İlk kurulan model olan Model 1'de, bağımlı değişken, yenilenebilir enerji tüketimi olarak belirlenmiştir. Bu model çalışmanın konusu açısından bulguları öncelikli önem arz eden modeldir. Model 1'de sabit terim dahil olmak üzere diğer değişkenler olan cari işlemler dengesi, enflasyon oranı, ekonomik büyüme, bütçe açı ̆̆ı, işsizlik ve petrol fiyatı verileri açıklayıcı değişken olarak modelde yer almıştır. Model 1, çalışmada yer alan diğer değişkenlerin, yenilenebilir enerji tüketimi üzerindeki etkilerini analiz eden modeldir. Tablo 6'nın ikinci sütununda, Model 1'in sonuçları yer almaktadır. Model 1'de uzun dönem için elde edilen sonuçlar tablonun üst tarafinda yer almaktadır ve uzun dönem için ortaya çıkan bulgular incelendiğinde; çalışmaya konu olan OECD ülkelerinde cari açığın artması ya da cari fazladaki azalışlar ile yenilenebilir enerji tüketimi arasında, uzun dönemli bir ilişkinin vardır. Bu ilişkinin uzun dönemli olması ve bu ülkelerde cari dengede ortaya çıkan cari fazlanın azalmasının ve / veya cari açığın oluşmasının, söz konusu ülkeleri yenilenebilir enerji kaynaklarına yöneltiyor olduğu görülmektedir. Başka bir anlatım ile cari denge ile yenilenebilir enerji tüketimi arasında uzun dönemde negatif bir ilişki söz konusudur. Kısa dönemde cari işlemler dengesinde meydana gelen ve cari işlemler açığındaki azalma ve / veya cari işlemler fazlasındaki artış kısa dönemde yenilenebilir enerji tüketimi üzerinde pozitif bir etkiye sahiptir.

Diğer önemli sonuç, ekonomik büyümenin, yenilenebilir enerji tüketimini uzun dönemli ve pozitif yönde etkilediğidir. Ekonomik büyüme yenilenebilir enerji kullanımını artırmaktadır. Enflasyonun yenilenebilir enerji tüketimine olan etkisi incelendiğinde uzun dönemli negatif bir ilişkinin varlığı görülmüştür. Enflasyondaki düşüş yenilenebilir enerji tüketimini uzun dönemde artırmaktadır.

Model 1'in bulguları incelendiğinde yenilenebilir enerji tüketimi üzerinde en önemli etkiye sahip değişkenin $\mathrm{CO} 2$ salınımı olduğu görülmüştür. $\mathrm{CO} 2$ salınımındaki artışlar güçlü biçimde yenilenebilir enerji tüketimini uzun dönemli olarak artırmaktadır. Başka bir anlatımla yenilenebilir enerji tüketimi üzerinde CO2 salınımının uzun dönemli güçlü ve pozitif bir etkisinin olduğu görülmektedir. CO2 salınımının yenilenebilir enerji tüketimi üzerindeki kısa dönemli etkisi incelendiğinde farklı bir tablo ortaya çıkmaktadır. Kısa dönemde geleneksel enerji kaynaklarına yönelim ve dolayısı ile artan CO2 salınımının yenilenebilir enerji kullanımını güçlü bir şekilde azalttığı görülmektedir.

Çalışmada yer alan bir diğer değişken olan petrol fiyatları incelendiğinde, uzun dönemde petrol fiyatlarındaki artışların yenilenebilir enerji kullanımı üzerinde pozitif bir etkisinin olduğu açıkça izlenebilmektedir. Bu bulgu petrol kullanımının maliyet avantajının azalması durumunda yenilenebilir enerji kaynaklarına yönelimin arttığını göstermektedir. Ayrıca 2007-2008 küresel krizini temsil eden kukla değişkenin kısa ve uzun dönemli olarak yenilenebilir enerji tüketimi üzerinde istatistiksel olarak anlamlı bir etkisinin olmadığı da gözlenmiştir. Diğer 
kurulan modeller, yenilenebilir enerji değişkeninin diğer değişkenler üzerinde ne derecede etkili olduğunu ortaya koyma amacını taşımaktadır. Elde edilen bulgular diğer beş model için yenilenebilir enerji kullanımın bağımlı değişkenler üzerinde kayda değer bir etkisinin olmadığını ortaya koymuştur.

\section{Sonuç}

Elde edilen bulgular incelendiğinde ilk göze çarpan durum, yenilenebilir enerji tüketimi üzerinde en önemli etkiye sahip ve en güçlü belirleyicinin $\mathrm{CO} 2$ salınımı olduğu görülmüştür. CO2 salınımındaki artışlar güçlü biçimde yenilenebilir enerji tüketimini uzun dönemli olarak artırmaktadır. Başka bir anlatımla yenilenebilir enerji tüketimi üzerinde $\mathrm{CO} 2$ salınımının uzun dönemli güçlü ve pozitif bir etkisinin olduğu görülmektedir. Bu bulgu yenilenebilir enerji kaynaklarına yönelimde en güçlü unsurun çevre olduğunu ortaya koymaktadır.

Çalışmada görülen diğer bir sonuç, araştırmaya konu olan ülkelerde cari işlemler dengesinde görülen, cari açı̆̆ın artması ya da cari fazlanın azalması gibi gelişmeler ile yenilenebilir enerji tüketimi arasında uzun dönemli pozitif bir ilişkinin varlığgdır. Cari dengede ortaya çıkan olumsuz durumlar araştırmaya konu olan ülkeleri yenilenebilir enerji kullanımına doğru yöneltmektedir. Bu durum çoğunluğu enerji ithal eden ülkeler açısında beklenen bir sonuçtur. Söz konusu ülkelerin enerji ithalatının ikamesi olarak yenilenebilir enerji kaynaklarına yöneldiği anlaşılmaktadır. Diğer yandan cari denge ile yenilenebilir enerji kullanımı arasındaki kısa dönemli ilişki farklı dinamikleri göz önüne sermektedir.

Cari işlemler dengesinde meydana gelen ve cari açıktaki azalma veya cari fazladaki azalış kısa dönemli olarak yenilenebilir enerji tüketimi üzerinde pozitif bir etkiye sahip olduğu görülmüştür. Bu durum kısa dönemde dış ticaret dengesinde ortaya çıkan ve söz konusu ülkelerin refah artışına neden olan gelişmelerin bu ülkeleri yenilenebilir enerji kaynaklarına yönelttiğini ortaya koyması açısından önemlidir. Refah artışı, çevre bilinci ve yenilenebilir enerji kullanımı arasındaki dinamikler göz önüne alındığında kısa dönemli bu sonuç da oldukça tutarlıdır.

Çalışmada elde edilen bir başka önemli bulgu, ekonomik büyüme ile yenilenebilir enerji tüketimi arasında uzun dönemli ve pozitif yönde bir ilişkinin olduğudur. Buna göre ekonomik büyüme ve artan refah çevre bilincini artırmakta ve yenilenebilir enerji kullanımını pozitif yönde etkilemektedir. $\mathrm{Bu}$ bulgu literatürdeki pek çok çalışmanın bulgusu ile de benzerlik arz etmektedir.

Enflasyonun yenilenebilir enerji tüketimine olan etkisi incelendiğinde uzun dönemli negatif bir ilişkinin varlığı görülmüştür. Çalışmaya konu olan ülkelerde enflasyondaki düşüş yenilenebilir enerji tüketimini uzun dönemde artırmaktadır. $\mathrm{Bu}$ noktada iki önemli faktör ortaya çıkmaktadır. İlki enerji maliyetlerindeki değişimin enflasyon üzerindeki etkisidir. Artan enerji maliyetleri enflasyonu 
olumsuz etkilemektedir. Bu nedenle enflasyon ile mücadele için düşük maliyetli geleneksel enerji kaynaklarına yönelimin artması beklenir. Diğer faktör ise geleneksel enerji kaynaklarının, yenilenebilir enerji kaynaklarına kıyasla çoğu alanda maliyet avantajı olmasıdır. Bu dinamik göz önüne alındığında çalışmanın bulgusu tutarlılık arz etmektedir.

Bir başka bulgu ise uzun dönemde petrol fiyatlarındaki artışlar ile yenilenebilir enerji kullanımı arasında pozitif bir ilişkinin varlığıdır. $\mathrm{Bu}$ sonuç, petrol fiyatlarındaki artışların alternatifi olan yenilenebilir enerji kullanımını pozitif yönde etkilediğini ortaya koyması bakımından beklenen bir bulgudur.

Çalışmada yer alan değişkenler üzerinde yenilenebilir enerji kullanımının etkisinin ne olduğu kurulan farklı modeller ile araştırılmıștır. Elde edilen sonuçlar bu değişkenler üzerinde yenilenebilir enerji kullanımının önemli bir belirleyici olmadığını göstermiştir. Bu bulgu da oldukça anlamlıdır çünkü söz konusu değişkenler yenilenebilir enerji dışındaki çok sayıda güçlü farklı değişkenler ile etkileşim halindedir. Diğer yandan söz konusu sonuç ekonomiler için yenilenebilir enerji kullanımının henüz diğer değişkenleri güçlü biçimde etkileyecek düzeye gelmemiş olduğunu yansıtmaktadır.

Kısaca bulgular özetlenecek olursa çevre etkileri yenilenebilir enerji kullanımında ekonomi dışı önemli bir faktör olarak ön plana çıkmaktadır. Ayrıca cari denge, araştırmaya konu olan ve yoğunlukla enerji ithal eden ülkelerde yenilenebilir enerji tüketimini etkileyen bir diğer faktördür. Ekonomik büyüme ve refah artışı da yenilenebilir enerji kullanımını olumlu yönde etkilemektedir. Enflasyon ise henüz yüksek yatırım maliyetleri sahip olan yenilenebilir enerji kullanımı ile negatif yönde etkileşime sahip bir makro ekonomik değişken olduğu anlaşılmıştır. Petrol fiyatlarındaki artışların, bu ülkeleri yenilenebilir enerji kaynaklarına yönlendirmesi ise çalışmada elde edilen bir diğer sonuçtur.

$\mathrm{Bu}$ sonuçlar kapsamında yenilenebilir enerji kullanımının artırılmasının, çevre bilinci ve eğitim ile ilişkili olduğu görülmektedir. Bu nedenle konuya ilişskin toplumsal eğitim programlarının yaygınlaştırılmasının önemli bir politika aracı olduğu ortaya çıkmaktadır. Bu sayede yenilenebilir enerji kullanımı ve dolayısı ile çevrenin korunması açısından başarı sağlanabilir. Diğer yandan enerji ithal eden ülkeler açısından, yenilenebilir enerji kullanımını yaygınlaştırmak ve cari dengeyi uzun vadede olumlu yönde etkilemek için yenilenebilir enerji kullanımına yönelik, vergi teşvikleri ve sübvansiyon benzeri politikaların uygulanmasının bir diğer politika seçeneği olduğu söylenebilir. Ekonomik büyümeyi ve refahı artıran politikaların da yenilenebilir enerji kullanımını artırması, sürdürülebilir büyüme temelli politikaların önemini ortaya koymuştur. Diğer yandan bu konuda uygulanabilecek en kritik politikaların yapısal temellere dayanması gerektiği anlaşılmaktadır. $\mathrm{Bu}$ politikaların yenilenebilir enerji üretim maliyetlerini düşürmeyi hedefleyen politikalar olması halinde, özellikle enerji ithal eden ülkeler için yenilenebilir enerji kullanımı, enflasyon ile mücadele için önemli bir araç 
haline gelecektir. Bu sayede yenilenebilir enerji kullanımı, aynı zamanda kısa ve uzun vadede ekonomik büyüme hedeflerini de destekleyen bir pozisyona sahip olacaktır. Özetle yenilenebilir enerji kaynaklarının çeşitlendirilmesi ve yaygınlaşması ve bu kaynakların maliyetlerinin düşürülmesi için yenilenebilir enerji teknolojilerine teşvik ve sübvansiyonların yanı sıra, AR-GE desteklerinin de artırılmasının sürdürülebilir ekonomik büyüme açısından büyük önem taşıdığı görülmüştür.

\section{Kaynakça}

Al-Mulali, U., Ozturk, I., ve Lea, H.H. (2015). The influence of economic growth, urbanization, trade openness, financial development, and renewable energy on pollution in Europe. Nat. Hazards, 79, 621- 644.

Anderson, T. W., ve Hsiao, C. (1982). Formulation and estimation of dynamic models using panel data. Journal of econometrics, 18(1), 47-82.

Anderson, T. W., ve Hsiao, C. (1981). Estimation of dynamic models with error components. Journal of the American Statistical Association, 76(375), 598-606.

Apergis, N., Payne J.E., Menyah, K., ve Wolde-Rufael, Y. (2010). On the causal dynamics between emissions, nuclear energy, renewable energy, and economic growth. Ecological Economics, 69, 2255-2260.

Arellano, M. (1989). A note on the Anderson-Hsiao estimator for panel data. Economics Letters, 31(4), 337-341.

Arellano, M., ve Bover, O. (1995). Another look at the instrumental variable estimation of error-components models. Journal of econometrics, 68(1), 29-51.

Baum, C. F., Schaffer, M.E., ve Stillman S. (2003). Instrumental variables and GMM: Estimation and testing. The Stata Journal, 3(1), 1-31.

Bhattacharya, M., Churchill, S., Awaworyi, P., ve Sudharshan, R. (2017). The dynamic impact of renewable energy and institutions on economic output and $\mathrm{CO}_{2}$ emissions across regions. Renewable Energy, 111, 157-167.

Bird, L., Bolingerb , M., Gaglianoc, T., Wiserb, R., Brown, M., ve Parsons, B. (2005). Policies and market factors driving wind power development in the United States. Energy Policy, 33, 1397-1407. 
Bloch, H., Rafiq, S., ve Salim, R. (2015). Economic growth with coal, oil and renewable energy consumption in China: Prospects for fuel substitution. Economic Modelling, 44, 104-115.

Bölük, G., ve Mert, M. (2014). Fossil \& renewable energy consumption, GHGs (greenhouse gases) and economic growth: evidence from a panel of EU (European Union) countries. Energy, 74, 439-446.

BP Veri Taban1, CO2 Emisyonu ve Ham Petrol Fiyatları https://www.bp.com/en/global/corporate/energy-economics/statisticalreview-of-world-energy.html (Erişim Tarihi: 10.01.2020)

Breitung, J., ve Das, S. (2005). Panel unit root tests under cross-sectional dependence. Statistica Neerlandica, 59(4), 414-433.

Chang, T.H., Huang , C.M., ve Lee, M.C. (2009). Threshold effect of the economic growth rate on the renewable energy development from a change in energy price: evidence from OECD countries. Energy Policy, 37, 5796-5802.

Dünya Bankası Veri Tabanı Cari İşlemler Dengesi, https://data.worldbank.org/indicator/BN.CAB.XOKA.CD Erişim tarihi:25.12.2019

Dünya Bankası Veri $\quad$ Tabanı $\quad$ Ekonomik Büyüme,https://data.worldbank.org/indicator/NY.GDP.MKTP.KD Erişim tarihi:29.12.2019

Dünya Bankası Veri Tabanı Enflasyon Oranı, https://data.worldbank.org/indicator/FP.CPI.TOTL.ZG Erişim tarihi:29.12.2019

Dünya Bankası Veri Isssizlik $\quad$ Orabanı https://data.worldbank.org/indicator/SL.UEM.TOTL.ZS Erişim tarihi: 10.01 .2020

Dvořáka, P., Martinátb, S., Horstc, D.V., Frantáld B., ve Turečková K. (2017). Renewable energy investment and job creation; a cross-sectoral assessment for the Czech Republic with reference to EU benchmarks. Renewable and Sustainable Energy Reviews, 69, 360-368.

Hillebrand, B., Buttermann, H.G., Behringer, J.M., ve Bleuel M. (2006). The expansion of renewable energies and employment effects in Germany. Energy Policy. 34, 3484-3494. 
Ibrahiem, D.M. (2015). Renewable electricity consumption, foreign direct investment and economic growth in Egypt: An ARDL approach. Procedia Economics and Finance, 30, 313- 323.

Igliński, B., Iglińska, A., Anna, C., Marcin, K.W. ve Buczkowski, R. (2016). Renewable energy production in the Lodzkie Voivodeship. The PEST analysis of the RES in the voivodeship and in Poland. Renewable and Sustainable Energy Reviews, 58,737-750

Inglesi-Lotz, R. (2016). The impact of revewable energy consumption to economic growth: A Panel data application. Energy Economics, 53, 58-63.

Ito, K. (2017). $\mathrm{CO}_{2}$ emissions, renewable and non-renewable energy consumption, and economic growth: evidence from panel data for developing countries. International Economics ,151,1-6.

Jebli, M.B., Farhani, S., ve Guesmi, K. (2020). Renewable energy, $\mathrm{CO}_{2}$ emissions and value added: Empirical evidence from countries with different income levels. Structural Change and Economic Dynamics , 53, 402-410.

Khattak, S. I., Ahmad M., Khan Z.U. ve Khan, A. (2020). Exploring the impact of innovation, renewable energy consumption, and income on $\mathrm{CO}_{2}$ emissions: new evidence from the BRICS economies. Environmental Science and Pollution Research, 27, 13866-13881.

Menyah, K., ve Wolde-Rufael, Y. (2010). $\mathrm{CO}_{2}$ emissions, nuclear energy, renewable energy and economic growth in the US. Energy Policy 38, 2911-2915.

OECD Veri Tabanı, Bütçe Dengesi, https://data.oecd.org/gga/generalgovernment-deficit.htm Erişim tarihi:25.12.2019

OECD Veri Taban1, Yenilenebilir Enerji, https://data.oecd.org/energy/renewableenergy.htm Erişim tarihi:10.01.2020

Pedroni, P. (1999). Critical values for cointegration tests in heterogeneous panels with multiple regressors. Oxford Bulletin of Economics and Statistics, 61(S1), 653-670.

Pedroni, P. (2004). Panel cointegration: asymptotic and finite sample properties of pooled time series tests with an application to the PPP hypothesis. Econometric Theory, 20(3), 597-625. 
Pesaran, M. H., Shin, Y., ve Smith R.P. (1999). Pooled mean group estimation of dynamic heterogeneous panels. Journal of the American Statistical Association, 94(446), 621-634.

Pesaran, M. H., ve Smith R. (1995). Estimating long-run relationships from dynamic heterogeneous panels. Journal of econometrics, 68(1), 79-113.

Peters, G. P., Marland, G., Le Quéré, C., Boden, T., Canadell J.G., ve Raupach M.R. (2012). Rapid growth in $\mathrm{CO}_{2}$ emissions after the 2008-2009 global financial crisis. Nature Climate Change, 2(1), 1-3

Sadorsky, P. (2009). Renewable energy consumption and income in emerging economies. Energy Policy; 37, 4021-4028

Shah, I. H., Hiles, C., ve Morley, B. (2018). How do oil prices, macroeconomic factors and policies affect the market for renewable energy? Applied Energy, 215, 87-97

Vaona, A. (2016). The effect of renewable energy generation on import demand. Renewable Energy, 86, 354-359.

Wei, M., Patadia, S. ve Kammen, D.M. (2010). Putting renewables and energy efficiency to work: How many jobs can the clean energy industry generate in the US? Energy Policy 38, 919-931

Westerlund, J. (2005). New simple tests for panel cointegration. Econometric Reviews, 24(3), 297-316. 


\title{
Macroeconomic Determinants of Renewable Energy Consumption in Selected OECD Countries
}

\author{
Extended Abstract
}

\section{Introduction}

Production technologies have played a crucial role in the economic structure throughout history. Energy, however, is one of the most fundamental inputs of production and the energy source to be utilized is largely determined by technology. The change in energy resources used, in other words, the discovery of new energy sources and developments such as the emergence of steam boilers have led to important economic leaps. Beyond the impacts of technological leaps and the use of new energy sources, energy is quite a critical production input. The bottlenecks and cost increases such as the oil crisis experienced in the energy sector have led to important paradigm shifts such as the end of the Keynesian trend. The current economic structure has reached an unsustainable dimension due to the depletion of conventional energy resources, and more importantly, the damage they caused to the environment. Within the framework of the latest technological improvements, it can be claimed that the world economy and lifestyle are on the verge of a tremendous transformation. It is expected that one of the main pillars of such change would be the efficient and widespread use of sustainable energy resources.

This research study addresses the determinants of renewable energy consumption. In this context, the factors triggering this process are investigated from a macroeconomic perspective. Upon conducting the research study, the selected OECD countries, which lead the advanced and technological innovations of the global economy, are investigated. The main macroeconomic determinants of renewable energy usage in these countries are examined. Besides, the relationship of renewable energy usage and oil prices with $\mathrm{CO} 2$ emissions is also examined. In summary, this research study analyzes macroeconomic variables as well as the impacts of $\mathrm{CO} 2$ emissions and oil prices on renewable energy usage from the macroeconomic perspective. For this purpose, a period interval, through which renewable energy usage becomes widespread, is chosen for the research study. Thus, it is tried to shed light on new trends in the energy domain, the relationship of these innovations with the selected variables, as well as possible improvements in the future. It is also aimed to provide the policymakers with recommendations.

\section{Method}

The annual data obtained from 26 OECD countries over the period 1996 - 2017 are utilized in the study. The conducted analysis covers the largest study period for which the data may be obtained. The data consist of the current account balance, budget balance, economic growth, inflation, renewable energy consumption, unemployment rate, carbon dioxide emissions, and crude oil prices.

First of all, the characteristics of the dataset are tried to be determined. In this context, crosssectional dependence of the variables is explicated, and both unit root tests and cointegration analyses are performed. It is understood that the data exhibit cross-sectional dependence. The variables are subjected to various panel unit root test analyses and it is found that some variables contain unit roots, whereas some of the variables do not contain unit roots. Therefore, it is tested whether cointegration exists among the variables, and as a result of the tests, it is determined that there is cointegration among the variables.

Upon examining the properties of the dataset, the Panel ARDL method developed by Pesaran and Smith (1999) and Pesaran et al. (1995) is seen as the most appropriate way to analyze the relationship among variables. Since the Panel ARDL method has a fixed effect and possess superior features such as the instrumental variables and GMM estimation methods compared to other dynamic panel data regression methods as seen in Anderson and Hsiao $(1981 ; 1982)$, 
Arellano (1989), and Arellano and Bover (1995). Unless the coefficients estimated across countries are the same, other methods are likely to yield erroneous results. In the light of the studies and applications in the literature, the Panel ARDL would be seen as the most appropriate method.

\section{Results and Discussion}

Upon examining the findings of the study, $\mathrm{CO} 2$ emission is seen as the variable having the most crucial impact on renewable energy consumption. Increases in $\mathrm{CO} 2$ emissions strongly aggravate renewable energy consumption in the long run. In other words, $\mathrm{CO} 2$ emissions are seen to have a strong and positive long-term impact on renewable energy consumption. Upon examining the short-term impact of $\mathrm{CO} 2$ emissions on renewable energy consumption, a different issue occurs. In the short run, it is seen that the tendency of using conventional energy sources, and thus, the increased $\mathrm{CO} 2$ emissions strongly reduce renewable energy usage.

Another finding asserts that a long-term relationship exists between the increase in the current account deficit (or the decrease in the current account surplus) and the renewable energy consumption for the OECD countries included in the analysis. The long-term nature of this relationship and the occurrences of the decline of current account surplus or the current account deficits are seen to lead these countries toward renewable energy resources. In other words, a negative relationship exists between the current account balance and renewable energy consumption in the long run. Another important obtained finding of the study involves the presence of a long-term and positive relationship between economic growth and renewable energy consumption. Accordingly, economic growth and increasing prosperity escalate environmental consciousness, and positively affect renewable energy usage. When the effect of inflation on renewable energy consumption is analyzed, it is seen that there is a long-term negative relationship. The decline of the inflation rate in the countries under examination increases renewable energy consumption in the long run.

\section{Conclusion}

As a result of the analysis, $\mathrm{CO} 2$ emission is seen as the most important and powerful determinant of renewable energy consumption. Another finding involves the existence of a long-term relationship between the increase in the current account deficit (or the decrease in the current account surplus) and the renewable energy consumption for the OECD countries under examination.

Within the scope of the findings, it is seen that increasing renewable energy usage is associated with environmental consciousness and education. Therefore, it appears that the dissemination of social education programs on the subject would be a crucial policy instrument. In this regard, success can be achieved in terms of renewable energy usage, and subsequently, the preservation of the environment. Nonetheless, for energy-importing countries, it can be claimed that the implementation of policies such as tax incentives and subsidies for renewable energy usage to expand the renewable energy usage and to positively affect the current account balance in the long-run would be another policy option. The fact that policies that increase economic growth, as well as welfare, also aggravate renewable energy usage reveals the importance of sustainable growth-based policies. On the other hand, it is understood that the most critical policies that may be implemented in this regard should be based on structural foundations. If these policies are aimed at reducing renewable energy production costs, renewable energy usage would become a crucial instrument to tackle inflation, especially for energy-importing countries. In this respect, renewable energy usage would also have a position that supports both short and long run economic growth targets. In short, it is observed that increasing R\&D incentives, as well as subsidies toward the renewable energy technologies to diversify and spread renewable energy resources and to reduce the costs of such resources, are of great importance in terms of sustainable economic growth. 